Research Article

\title{
Resistance Assessment of Citrus Varieties against Gummosis Disease caused by Phytophthora nicotianae under Natural Field Conditions
}

\author{
Hamza Tariq ${ }^{1}$, Nasir Ahmed Rajput ${ }^{1 *}$, Muhammad Atiq ${ }^{1}$, Shahbaz Talib Sahi ${ }^{1}$, Abdul Rehman ${ }^{1}$, Abdul \\ Rashid $^{1}$, Muhammad Ahsan Khan ${ }^{2}$, Akhtar Hameed ${ }^{1,3}$ and Warda Modassar Saddique ${ }^{1}$
}

${ }^{1}$ Department of Plant Pathology, University of Agriculture, Faisalabad, Pakistan; ${ }^{2}$ Department of Entomology, University of Agriculture, Faisalabad, Pakistan; ${ }^{3}$ Institute of Plant Protection, MNS-Agriculture University, Multan, Pakistan.

Abstract | Citrus gummosis caused by Phytophthora nicotianae is the most damaging disease of citrus. In the present study, twelve varieties of citrus were screened against gummosis under natural field conditions under Randomized Complete Block Design (RCBD). Among these varieties, Kumquat expressed a highly resistant response with lesion size $(0.750 \mathrm{~cm})$, Sweet Lemon exhibited resistant response with $(1.616 \mathrm{~cm})$ lesion size, Mangal Singh moderately resistant with rating (3) while two varieties i.e. Malta and Succari exhibited moderately susceptible response, three varieties i.e. Jaffa, Tangerine and China Lemon (4.066, 4.250, 5.100 $\mathrm{cm}$ ) lesion size respectively showed susceptible response while four varieties (Tracco, Rough Lemon, Kinnow, Grapefruit) exhibited highly susceptible response with the rating (7). Kumquat shows a resistance response in a present study and Grapefruit shows highly susceptible results during the experiment.

Received | December 15, 2020; Accepted | October 06, 2021; Published | October 23, 2021

*Correspondence | Nasir Ahmed Rajput, Department of Plant Pathology, University of Agriculture, Faisalabad, Pakistan; Email: nasirrajput81@gmail.com

Citation | Tariq, H., N.A. Rajput, M. Atiq, S.T. Sahi, A. Rehman, A. Rashid, M.A. Khan, A. Hameed and W.M. Saddique. 2021. Resistance assessment of citrus varieties against gummosis disease caused by Phytophthora nicotianae under natural field conditions. Pakistan Journal of Agricultural Research, 34(4): 824-829.

DOI | https://dx.doi.org/10.17582/journal.pjar/2021/34.4.824.829

Keywords | Citrus gummosis, Phytophthora nicotianae, Assessment, Varieties, Lesion

\section{Introduction}

Oite itrus is one of the most edible fruits in the world belongs to the family Rutaceae, grown in tropical and subtropical climatic areas of the world (Khalid et al., 2018). The presence of vitamins, minerals, dietary fiber, metabolites, carbohydrates, and a variety of phytochemicals made it nutritionally rich and helps to cure multiple diseases (Rafiq et al., 2016). Pakistan's climate is favorable for the production of citrus, but unfortunately, Pakistan has less production than other developing countries due to multiple diseases ( $\mathrm{Ri}$ asat et al., 2020). Global climatic conditions, different biotic, and abiotic factors have an adverse effect on the citrus which results in increasing the intensity of diseases like canker, greening, wither tip, scab, black pit, alternaria brown spot, and gummosis (Malik and Khan, 2014) but citrus gummosis which is soil born disease, is, the most dangerous one and is destroying the citrus industry of all the major citrus growing areas of the world (Rajput et al., 2020). Every year 10-30 of citrus production is lost due to gummosis (Mounde et al., 2009). Oozing of gum from the stem is the main symptom of gummosis (Rajput et al., 2020), adult plants show chlorosis, twig dieback, decline discolored fruits, etc. (Naqvi, 2004). The appearance of dark areas under bark and sour smell, exudation of water-soluble gum from cracks in the bark, yellowing of foliage, and death of plant are characteristic symptoms of this disease. Bleeding appearance of the plant due to exudation of gum which may wash due to rain-splash are some early symptoms of citrus December 2021 | Volume 34 | Issue 4 | Page 824 
gummosis. When Phytophthora attack on citrus plant, it causes cracking in firmness in the bark and spread in the whole perimeter of the trunk (Sadowsky, 2006).

Many management strategies like the use of resistant varieties, chemicals, phytoextracts, biocontrol agents, and cultural practices, are under consideration and different trials are being conducted to manage citrus gummosis but the main approach to manage citrus gummosis is the use of resistant sources because it is most economical and ecofriendly one. For this purpose, screening of available germplasm is prerequisite. Due to this reason in the current study twelve varieties were evaluated through artificial inoculation because it is a long-term solution of the plant diseases (Hameed et al., 2020).

\section{Materials and Methods}

\section{Sample collection for isolation of pathogen-associated with citrus gummosis}

Diseased samples with characteristic symptoms were collected from the research area Institute of Horticultural Sciences (IHS), University of Agriculture Faisalabad (UAF). Mainly roots and specifically feeding roots were collected Then these samples were shifted to the citrus pathology lab. Department of Plant Pathology for further process by adopting precautionary measures. Diseased samples specifically root which showed blackish color were cut down into small pieces (2-3 $\mathrm{mm}$ in size) and washed under tap water. Then for surface sterilization, samples were passed through $70 \%$ ethanol for 30 seconds and then 3 times through distilled water for 30 seconds. For isolation of pathogen corn meal agar (CMA) media was prepared. For the preparation of cornmeal agar media, 15 gm cornmeal along with 2 gm agar was added in one liter distilled water in a glass bottle and heated it slowly to dissolve all the nutrients. Then after putting a cap on the bottle, autoclaved it for 15 minutes at $121^{\circ} \mathrm{C}$. When the temperature of the media becomes $45^{\circ} \mathrm{C}$ then pour $5 \mathrm{~mL}$ of CMA into Petri plates. After this small pieced of diseased samples were placed in the Petri plates with the help of sterilized forceps and placed in the incubator fungal growth was appeared on the CMA media which was purified for further process.

Purification and identification of pathogen-associated with citrus gummosis

For purification of the pathogen, free from bacteria, the glass ring method was used (Raper, 1937). A glass

ring (15 mm dia.) was put in the middle of the Petri plate containing CMA media and fill half of the ring with media and a piece of CMA containing mycelial growth in the middle of the glass ring in the Petri plate and placed them in the incubator at $22-25^{\circ} \mathrm{C}$. Pure growth of the pathogen was obtained beneath the glass ring after 48 hours and was shifted to another Petri plate containing CMA and this process was repeated three times to get pure culture and the pathogen was identified on the basis of morphological characters like the structure of sporangia, zoospore, and sexual structures as described by Hall (1993), Ho (1995), Khulbe (2001), de Cock et al. (2004) and Boughalleb-M'hamdi et al. (2018).

\section{Screening of citrus germplasm against gummosis caused by Phytophthora nicotianae}

In the year 2019 and 2020, twelve, different varieties of citrus having age of 2 years were collected from the horticulture nursery (32 Square) of UAF and brought them to citrus research laboratory, Department of Plant Pathology, University of Agriculture, Faisalabad and were shifted to the citrus research area, Department of Plant Pathology. These varieties were sown in the field by maintaining row to row $(R$ $\times \mathrm{R})$ and plant to plant $(\mathrm{P} \times \mathrm{P}) 90 \mathrm{~cm}$ distance under Randomized Complete Block Design (RCBD) in the field with three replications. After the establishment of citrus varieties were artificially inoculated through soil drenching with $10^{5}$ to $10^{6}$ zoospores in the root zoon of each citrus plant of all varieties under field conditions. To maintain the nursery in healthy conditions, all the recommended horticultural practices like pruning, sanitary conditions were maintained, and varieties were graded by following Gade et al. (2006) (Table 1).

\section{Table 1: Rating scale used to identify the response of cit- rus varieties towards gummosis.}

\section{Ratings Lesion size}

0

1

No oozing and $0 \mathrm{Cm}^{2}$ lesion size

Oozing and lesion developed up to $1 \mathrm{Cm}^{2}$ area

3 Oozing and lesion developed up to $1-2.5 \mathrm{Cm}^{2}$ area

$5 \quad$ Oozing and lesion developed up to $2.5-5 \mathrm{Cm}^{2}$ area

$7 \quad$ Oozing and lesion developed up to $\geq 5 \mathrm{Cm}^{2}$ area

$9 \quad$ Oozing and bark splitting

\section{Response}

Immune

Resistant

Moderately $\mathrm{Re}-$ sistant

Susceptible

Moderately Susceptible

Highly susceptible 

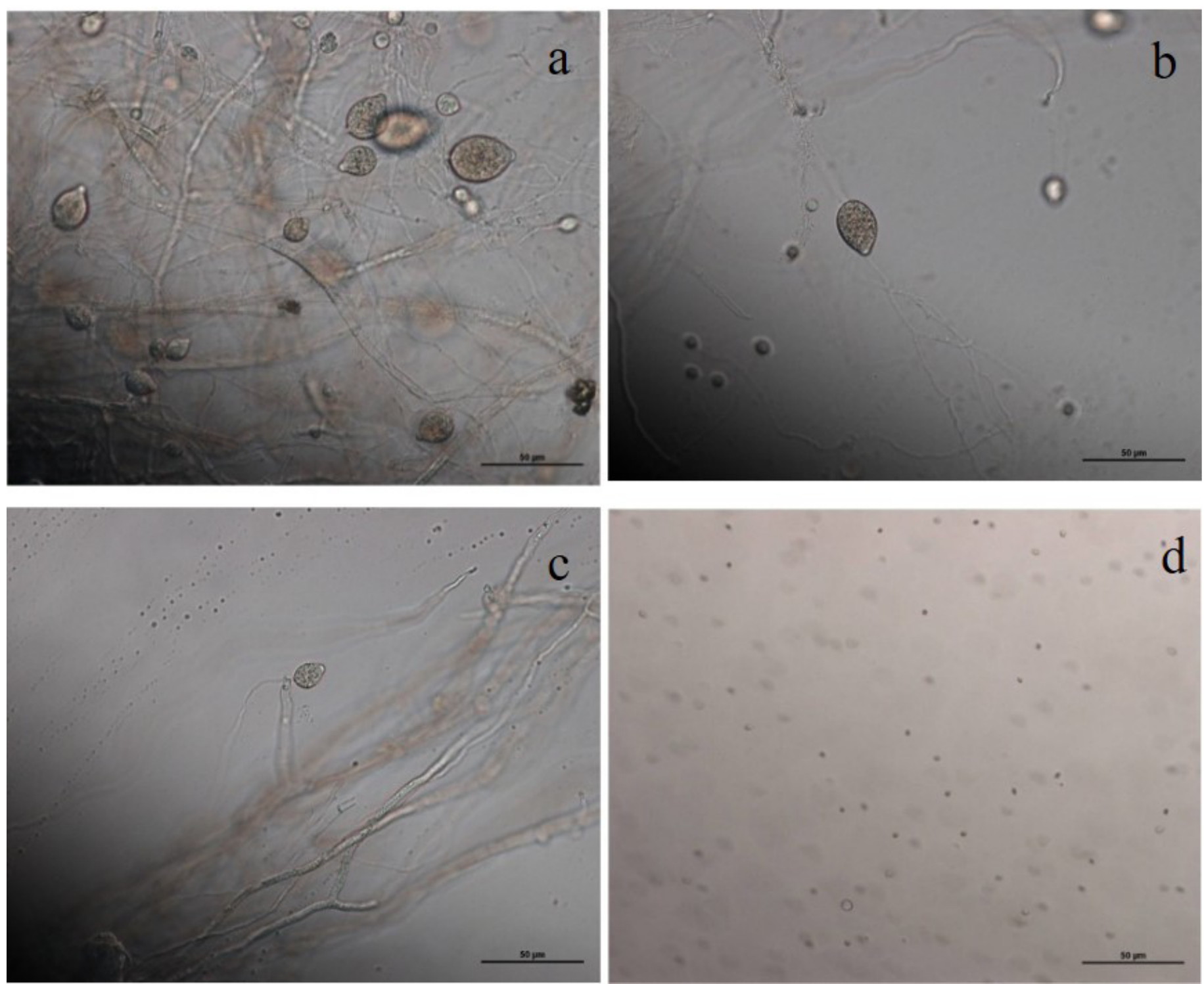

Figure 1: Morphological characteristics of Phytophthora nicotianae. a) Different shapes of zoosporangia, b) zoospore release directly from sporangium, c) branches of mycelia, d) oospores in water culture (scale bars: 50 $\mu \mathrm{m}$ ).

\section{Data analysis}

Data was statically analyzed by using SASS/ STAT (SAS institute, 1990). The least significant difference (LSD) was used to separate the means of all the treatments.

\section{Results and Discussion}

Identification of pathogen-associated with citrus gummosis

Size of sporangia of pathogen is $(6.0 \times 35.0$ to 33.3 $\times 24.5 \mu \mathrm{m}$ (average: $42 \times 29 \mu \mathrm{m}$ ) with a length-breadth ratio of $1.4: 1$. Its sporangiophore was observed sympodial branched, ovoid or obpyriform, non-caducous papillate sporangia $34.2-58.0 \mu \mathrm{m}$ long and 28.4-43.3 $\mu \mathrm{m}$ wide; and global, thick-walled, terminal, or intercalary chlamydospores and 24.5-50.7 $\mu \mathrm{m}$ in diameter, Coenocytic hyphae $7-10 \mu \mathrm{m}$ in diameter. Oospores measure 23-38 $\mu \mathrm{m}$ in diameter (average: $29 \mu \mathrm{m}$ ), These characters of pathogen expressed that is Phytophthora nicotianae var. nicotianae (Breda de Haan) (Figure 1).

Symptoms and disease development of citrus varieties during 2019 and 2020

The disease appeared in the field after twenty days of inoculation under field conditions. Symptoms appeared in the form of discoloration of roots, destruction, and rotting of feeding roots, yellowing of leaves and wilting, formation of the lesion with gum exudation were observed when the temperature was high with the maximum amount of relative humidity.

Response of citrus varieties towards gummosis caused by Phytophthora nicotianae under field conditions

In the year 2019, among twelve varieties of citrus, 
Kumquat expressed a highly resistant response with lesion size $(0.750 \mathrm{~cm})$, Sweet Lemon exhibited resistant response with $(1.616 \mathrm{~cm})$ lesion size, one variety Mangal Singh has shown moderately resistant response with rating scale (3) while two varieties i.e. Malta, Succari with rating scale (5) expressed moderately susceptible response, three varieties i.e. Jaffa, Tangerine, China Lemon (4.066, 4.250, $5.100 \mathrm{~cm}$ ) lesion size respectively showed susceptible response while four varieties (Tracco, Rough Lemon, Kinnow, Grapefruit) exhibited highly susceptible response with the rating (7) as shown in (Figure 1). Similar results were expressed by these varieties except China Lemon in the year 2019. In the first year's experiment, China Lemon showed a susceptible response while in 2020 it expressed a highly susceptible response as shown in (Figure 2).

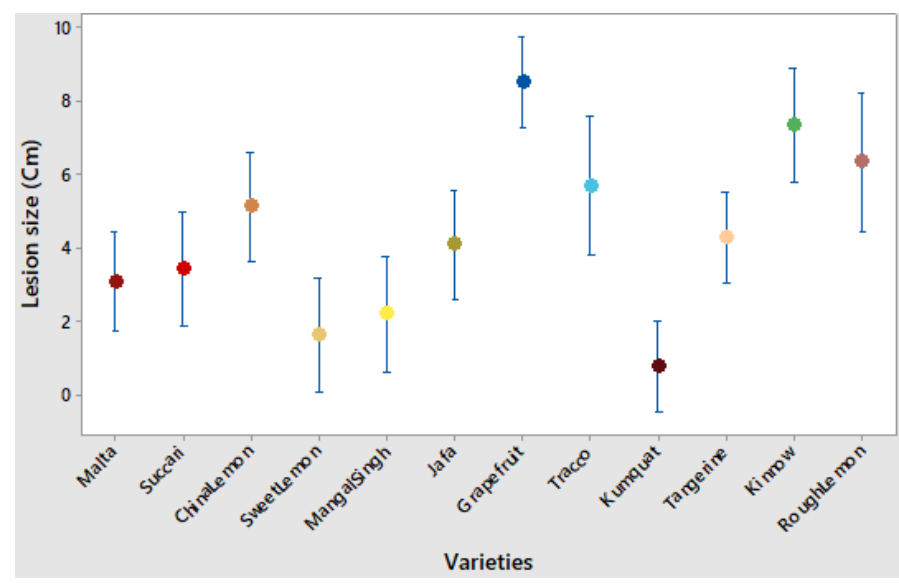

Figure 2: The response of different varieties against citrus gummosis disease under field conditions in 2019.

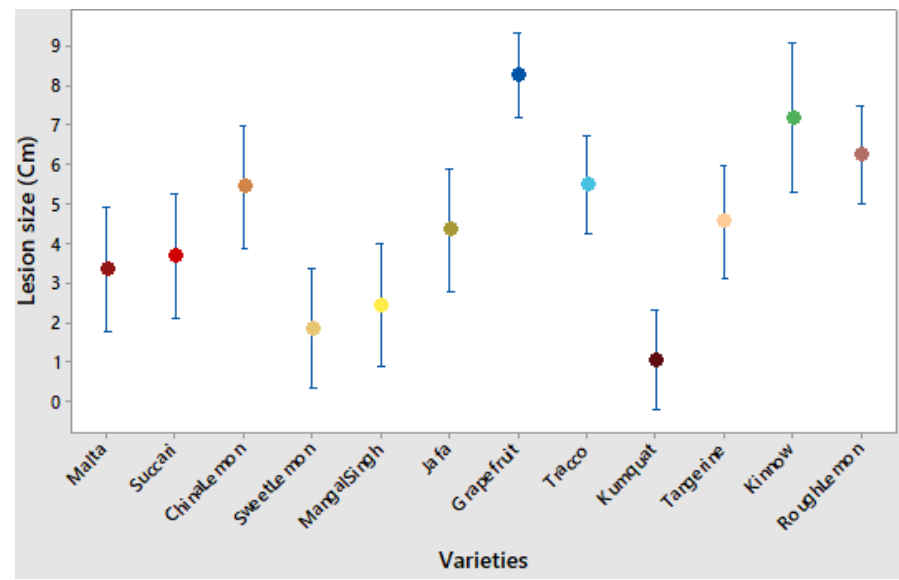

Figure 3: The response of different varieties against citrus gummosis disease under field conditions in 2020.

Citrus gummosis caused by Phytophthora species is one of the potential threats to citrus around the world (Graham and Feichtenberger, 2015), and it is estimated that $46 \%$ of citrus is damaged every year due to Gummosis (Savita et al., 2012). Slow decline, twig dieback, oozing of gum, yellowing of foliage, early flowering, the decline in the yield, and less fruit size are the major symptoms of this disease are observed in the current study which is supported by Naqvi (2004). Air temperature, high humidity (Rajput et al., 2020), soil temperature and flooding duration in the soil has a great impact on the severity and dynamics of Phytophthora nicotianae under the ground parts of the plant (Alvarez et al., 2009). Likewise, the presence of multiple strains of fungus, changing climatic conditions, susceptible varieties play an important role in the disease development of citrus gummosis (Naqvi, 2004). To reduce the disease incidence of soil-borne pathogens, the use of resistant hosts is the applicable and best method. Additionally, these resistant varieties not only diminish the incidence of disease but avoid residual effects of fungicides due to their usage in the soil as well (Naik et al., 2008).

Molecular techniques to transfer resistance genes is a cost-effective and time-consuming process, but screening of available citrus germplasm is short term, handy and helpful approach to identify resistance or susceptible varieties (Atiq et al., 2007; Jagtap, 2012). Farmers and researchers get more benefit from the varieties which are resistant to fungus (Agrios, 2005). That's why in 2019 and 2020, twelve different varieties were evaluated against citrus gummosis and it was observed that some potential source of resistance (High/ Moderate) is dominant in three cultivars (Kumquat, Sweet Lemon, Mangal Singh), some varieties (Malta, Succari, Jaffa, Tangerine) expressed moderately and susceptible results while one variety china lemon show susceptibility, but in next year it becomes highly susceptible. Similarly, four varieties named Tracco, Rough lemon, Kinnow grapefruit were screened out highly susceptible in both years but, as time passing the use of resistant cultivars in the exclusive area may reduce the resistance of these varieties due to the development of new infectious and strong strains of the pathogen. It is a better choice to use varieties having horizontal resistance due to the presence of multiple genes (Hameed et al., 2020). In a similar experiment, eight different rootstocks of citrus were evaluated by using freshly prepared spore suspension against Phytophthora nicotianae and this trial concluded that screening of the resistance rootstock of citrus against footrot is a helpful method (Amrinder et al., 2013). Benfradj et al., (2016) performed a similar experiment in which different citrus rootstock was evaluated against zoospores of $P$. nicotianae and it was con- 
cluded that screening of citrus varieties is necessary to control the damage and to transfer resistant rootstock for better results. Likewise, ten different citrus varieties were screened out under natural field conditions and it was evaluated that Kumquat showed a resistant response against citrus gummosis (Kumar and Chahal, 2018).

Kumquat showed a high resistance response due to its genetic makeup. Kumquat used by different researches for the supportive role towards finding resistance mechanisms due to some factors like cuticle development in leaf and size of new blooms and the presence of $\mathrm{H}_{2} \mathrm{O}_{2}$ than Grapefruit (Hameed et al., 2020). $\mathrm{H}_{2} \mathrm{O}_{2}$ in the plant helps in programmed cell death and effectively controlling pathogens (Marques et al., 2014). The presence and increased production of secondary metabolites such as flavonoids enhance the response against pathogens in citrus cultivars thus make them resistant (Munir et al., 2019).

\section{Conclusions and Recommendations}

Kumquat shows a resistance response in a present study and Grapefruit shows highly susceptible results during the experiment. Resistant or moderately resistant varieties of citrus which are identified during this screening process might be helpful in the future for the breeding of commercial resistant cultivars of citrus. Furthermore, the source of resistance should be incorporated in susceptible varieties to change their genotype. So, in the future kumquat and genetic material of kumquat can be used to get more yield and disease-free orchards.

\section{Acknowledgments}

This article is extracted from the M. Sc. (Hons.) dissertation of Hamza Tariq. We are highly great full to the Higher Education Commission of Pakistan for funding this research under the Project (NRPU HEC-9422) for this study.

\section{Novelty Statement}

The novelty of the contemporary research is to find out the source of resistance among the available citrus germplasm. The resistant germplasm will be highly valuable to continue the conventional / advanced breeding research programs. Likewise, it will also be helpful for farming community to diminish the dis- ease severity/incidence and consequently to enhance their economic return.

\section{Author's Contribution}

Hamza Tariq: Conducted research and wrote manuscript.

Nasir Ahmed Rajput and Muhammad Atiq: Conceived idea, gave technical inputs and supervised the research.

Shahbaz Talib Sahi and Abdul Rehman: Critically reviewed and edited the manuscript.

Abdul Rashid and Muhammad Ahsan Khan: Helped in writing manuscript.

Akhtar Hameed: Wrote results and discussion section and did necessary corrections.

Warda Modassar Saddique: Compiled research data.

Conflict of interest

The authors have declared no conflict of interest.

\section{References}

Agrios, G.N.2005. Plant Pathology (Fifth Edition). Elsevier Academic Press.

Alvarez, L.A., D. Gramaje, P. Abad-Campos and J. Gracia-Jimenez. 2009. Seasonal susceptibility of citrus scions to Phytophthora citrophthora and $P$. nicotianae and the influence of environmental and host-linked factors on infection development. Eu. J. Plant Pathol. 124: 621-635. https://doi.org/10.1007/s10658-009-9449-8

Amrinder, K., S.K. Verma and S.K. Thind. 2013. Screening of different citrus rootstocks against foot rot disease (Phytophthora nicotianae var. parasitica). Plant Dis. Res. 28: 49-52.

Atiq, M., M.A. Khan and S.T. Sahi. 2007. Screening of Citrus Germplasm for the Sources of Resistance against Canker Disease Caused by Xanthomonas axonopodis pv. citri. Pak. J. Phytopathol. 19(2): 222-226.

Benfradj, N., N. Metoui and N.B. Hamdi. 2016. Screening of tolerance of different citrus rootstocks against zoospores of Phytophthora nicotianae in infested soil. J. Phytopathol. Pest. Manage. 3: 63-75.

Boughalleb-M'hamdi, N., N. Benfradj, D. Migliorini, N. Luchi and A. Santini. 2018. Phytophthora nicotianae and P. cryptogea causing gummosis of citrus crops in Tunisia. Trop. plant pathol. 43: 36-48. https://doi.org/10.1007/ 
s40858-017-0180-2

de Cock, A.W.A.M. and C.A. Lévesque. 2004. New species of Pythium and Phytophthora. Stud. Mycol. 50: 481-487.

Gade, R.M., O.M. Bambawale, U.R. Sangale and V.B. Shinde. 2006. Chemical management of gummosis in Nagpur mandarin (Citrus reticulate Blanco). Pestic. Res. J. 18: 169-172.

Graham, J. and E. Feichtenberger. 2015. Citrus phytophthora diseases: Management challenges and successes. J. Citrus Pathol. 2:12-17. https:// doi.org/10.5070/C421027203

Hall,G.1993. An integrated approach to the analysis of variation in Phytophthora nicotianae and a redescription of the species. Mycol. Res. 97:559-574. https://doi.org/10.1016/S09537562(09)81179-9

Hameed, A., M. Atiq, N.A. Rajput, S.T. Sahi, S. Sarfraz, H.A. Alsamadany, A.M. Lodhi, F. A. Tahir, N. Liaqut and Z. Ahmed. 2020. Assessment of Genetic Potential of Citrus Germplasm against Citrus Canker Caused by Xanthomonas Axonopodis pv. Citri. Fresenius Environ. Bull. 29: 3557-3563.

Ho, H.H., Ann, P.J. and Chang, H.S. 1995. The genus Phytophthora in Taiwan. Inst. Bot. Acad. Sin. Monogr. Ser. 15.

Jagtap, G.P. 2012. Evaluation of plant extracts and bioagents for the control of gummosis of mandarian orange (Citrus reticulata blanko) caused by Phytophthora Species. Afr. J. Agric. Res. 4553-4558. https://doi.org/10.5897/ AJAR12.214

Khalid, H., M.J. Jaskani, M. Atiq, S.H. Khan, N.A. Rajput, I. Ahmad, M. Azam and S. Khalid. 2018. Evaluation of Botanicals and Fungicides against Seed Borne Fungi and Germination of Rough Lemon Seeds. Pak. J. Phytopathol., 31(2): 155-162. https://doi.org/10.33866/ phytopathol.030.02.0444

Khulbe, R.D. 2001. A Manual of Aquatic Fungi (Chytridiomycetes \& Oomycetes). Delhi, India: Daya Publishing House. 255.

Kumar, A. and T.S. Chahal. 2018. Studies on diseases and disorders of different citrus germplasm under natural condition.J. Entomol. Zool. Stud. 6: 406-409.

Malik, A.U. and I.A. Khan. 2014. Kinnow Quality Issues and strategies for improvement. USDA, University of Agriculture, Faisalabad, Pakistan.

Marques, J.P.R., L. Amorim, G.J. Silva-Junior,
M.B. Spoito and B.A. Gloria. 2014. Structural and biochemical characteristics of citrus flowers associated with defense against a fungal pathogen. Oxford University Press. http://aobpla.oxfordjournals.org/ https://doi. org/10.1093/aobpla/plu090

Mounde, L.G., E.M. Ateka, A.W. Kihurani, L. Wailwa and E.G. Thuranira. 2009. Occurrence and Distribution of Citrus Gummosis (Phytophthora Spp.) In Kenya. Afr. J. Hort. Sci. 2: 56-68.

Munir, N., A.A. Hameed, R. Haq and S. Naz. 2019. Biochemical changes in cultivars of sweet oranges infected with citrus tristeza virus. Braz. J. Biol., 79: 742-748. https://doi. org/10.1590/1519-6984.193791

Naik, M.K., G.S.D. Rani and H.M. Madhukar. 2008. Identification of resistant sources against wilt of chilli (Capsicum annum L.) caused by Fuarium solani (Mart.) Sacc. J. Mycopathol. Res. 46 (1): 93-96.

Naqvi, S.A.M.H. 2004. Diagnosis and management of certain important fungal diseases of citrus. In Diseases of Fruits and Vegetables, 1:247-290. https://doi.org/10.1007/1-4020-2606-4_5

Rafiq, S., R. Kaul, S.A. Sofi, N. Bashir, F. Nazir and G.A. Nayik. 2016. Citrus peel as a source of functional ingredient: A review. J. Saudi Soc. Agric. Sci. 17(4): 351-358. https://doi. $\mathrm{org} / 10.1016 / \mathrm{j} . j s s a s .2016 .07 .006$

Rajput, N.A., M. Atiq, H. Tariq, W.M. Saddique and A. Hameed. 2020. Citrus Gummosis: A Formidable challenge to citrus industry: A Review. Int. J. Biosci. (IJB), 16: 131-144.

Raper, J.R. 1937. A method of freeing fungi from bacterial contamination. Science, 85: 342. https://doi.org/10.1126/science.85.2205.342

Riasat, A., M.U. Ghazanfar and W. Raza. 2020. Interaction of citrus canker with Phyllocnistis citrella staintion. Pak. J. Phytopathol., 32(1): 1-7. https://doi.org/10.33866/ phytopathol.032.01.0490

Sadowsky, A. 2006. Lo stato fitosanitario degli agrumi in Israele. Informatore FitopatologicoLa difesa delle piante. 56: 42-47.

SAS Institute. 1990. SAS User's Guide: Statics. Version 6, 4th Edition, SAS institute Inc., Cary. Savita, G., N. Virk and A. Nagpal. 2012. Citrus Diseases caused by Phytophthora species. GERF Bull. Biosci. 3: 18-27. 